\title{
Pozorované změny složek hydrologické bilance z hlediska využitelných vodních zdrojů
}

\section{RADEK VLNAS}

Klíčová slova: hydrologická bilance - trend - R - odtok - vodní zdroje - základní odtok - vrty - prameny

\section{SOUHRN}

Příspěvek se zabývá sledováním změn $v$ časových řadách hydrologických bilančních veličin pomocí detekce trendu. $K$ dispozici byla řada různých datových sad, jako jsou data ze zpracování Hydrologické bilance množství a jakosti vody ČR, stanovení prírodních zdrojů podzemních vod a režimu podzemních vod. Tato kombinace dat různých veličin a časových měřitek umožňuje komplexně sledovat prípadné změny hydrologického cyklu. Jakkoli se jedná o relativně krátké raady délky několika desetiletí, jejich výhodou je podobné zpracovávané období, a tedy možnost vzájemného porovnání. K detekci trendu byl použit Mann-Kendallův test s korekcí autokorelace 1. rádu. Existence, velikost a plošná distribuce trendu byla popsána v řadách měsičních a ročních srážkových úhrnů, teplot vzduchu, evapotranspirace, odtoku a dalších veličin, dále $\checkmark$ měsíčních a ročních průměrech a minimech denních průtoků a základního odtoku a také vydatností pramenů a stavů hladin ve vrtech.

\section{ÚVOD}

Snaha pozorovat a vyhodnocovat složky hydrologické bilance stála již u zrodu pravidelných pozorování vodních stavů na našem území. V souvislosti se současnou diskusí o existenci, vývoji a dopadu klimatické změny na vodní zdroje nám tato úloha nabízí další perspektivu. Můžeme si totiž položit otázku, zda a jakým způsobem se složky hydrologické bilance vyvíjely v době pravidelného instrumentálního měření a zda jsou prípadné změny v souladu s odhady budoucího vývoje klimatu a jeho dopadů. K odpovědi na první část otázky jsme se pokusili přispět s využitím testování existence monotónního lineárního trendu v časových řadách některých vybraných bilančních veličin.

Důvodem použití relativně krátkých časových řad od počátku 70. nebo 80. let do současnosti je jejich příprava a využití v rámci různých pravidelných výkazů ČHMú, jakými jsou např́klad každoroční zpráva Hydrologická bilance množství a jakosti vody ČR, stanovení prírodních zdrojů podzemních vod nebo režim podzemních vod $v$ daném roce. Jakkoli se jedná o relativně krátké třiceti až čtyřicetileté řady, jejich výhodou je, že podobné zpracovávané období umožňuje jejich vzájemné porovnání.

Pro celé území ČR hodnotili změny bilančních veličin v poslední době Hanel aj. (2011) v rámci odhadu dopadů klimatické změny na hydrologickou bilanci, a to prostřednictvím rozdílů mezi průměry v období 1961-1980 a 1981-2005. Byl pozorován především nárůst teplot v ročním průměru o asi $0,6-1,2^{\circ} \mathrm{C}$. Růst teplot vede k růstu potenciální evapotranspirace o řádově 5-10 \% na jaře a v létě. Růst potenciální evapotranspirace je na velké části území ČR kompenzován růstem srážek. V roční bilanci činí tento nárůst až $10 \%$. Z rozdílu srážek a potenciální evapotranspirace vyplývá zhoršení vodní bilance na jaře v Čechách a v létě na Moravě (především severní) a na podzim zlepšení vodní bilance na celém území ČR kromě Polabí, kde ke změně bilance nedochází.

Trendy v řadách sedmidenních klouzavých minim průtoků ve 144 vodoměrných stanicích v období 1961-2005 se zabývali Fiala aj. (2010). V letním období zjistili trend poklesu minim u $12 \%$ stanic, které byly soustředěny v povodí horní a části střední Moravy a dále se vyskytovaly v několika povodích levostranných př́toků středního Labe. Pouze u jedné stanice byl zjištěn trend nárůstu letních minim. Naopak v minimech zimního období nalezli statisticky významný pozitivní trend u 14 \% stanic. Jednalo se o stanice v horských oblastech. Nárůst zimních minimálních průtoků autoři připisují teplejším zimám s větším podílem kapalných srážek.

Hodnocením trendů vydatností pramenů v období 1971-2007, sledovaných jako součást pozorovací sítě ČHMÚ, se zabývali Ledvinka a Lamačová (2015). Jejich hodnocení je zaměřeno spíše na existenci plošně platného trendu $\checkmark$ rámci členění ČR na hydrogeologické rajony než na jednotlivé prameny. Výsledky ukázaly, že $v$ ročních řadách vydatností pramenů je ve 12 z 18 rajonů př́tomen negativní trend, tedy pokles vydatností, avšak je-li prí stanovení Mann-Kendallovy statistiky zahrnut také vliv kř́žové korelace mezi prameny, jak doporučují autoři, klesá vydatnost pouze ve čtyřech rajonech. Tyto rajony se nacházejí ve středních Čechách a na jižní a severní Moravě.

\section{DATA}

$\checkmark$ této studii byly zpracovány následující tři typy dat: (a) bilanční veličiny z výkazů Hydrologické bilance množstvía jakosti vody ČR, kterou podle zákona č. 254/2001 Sb., o vodách a vyhlášky Ministerstva zemědělství č. 431/2001 Sb. každoročně zpracovává ČHMÚ (2015a). Jedná se o tyto veličiny: srážkové úhrny, zásoba vody ve sněhu, teplota a relativní vlhkost vzduchu, potenciální a aktuální evapotranspirace, pozorované a přirozené průtoky. Veličiny jsou evidovány v měsíčních průměrech, popř. úhrnech. Termínem přirozené průtoky se rozumí průtoky očištěné od vlivu odběrů, vypouštění a manipulací na nádržích. Vzhledem k návaznosti na přirozené průtoky, jejichž evidence je vedena od roku 1979, zahrnují všechny uvedené veličiny období 1980-2013. Existence trendu byla šetřena $v$ jednotlivých bilančních povodích (74 povodí) a v bilančních oblastech (10 oblastí) zvlášt pro jednotlivé měsíce roku a pro roční agregace veličin.

Další skupinu dat představují (b) data ze zpracování prírodních zdrojů podzemních vod ČR. Jedná se o řady denních pozorovaných průtoků a základního odtoku ve 161 vodoměrných stanicích v období 1971-2013. Základní odtok byl separován metodou podle Eckhardta (2005) s roční korekcí parametru BFImax, který při takové separaci není pro celé období konstantní, ale je odvozen pro každý rok zvlášt metodou klouzavých minim. Tento způsob separace lépe 
charakterizuje pririrozenou víceletou variabilitu odtoku a změn zásob podzemní vody. Přítomnost trendu byla zjištována v řadách průměrných a minimálních měsičních a ročních hodnot obou veličin. Pro odstranění vlivu extrémně nízkých hodnot při zpracování minim byly řady pred měsiční a roční agregací vyhlazeny pomocí sedmidenních klouzavých průměrů.

Poslední skupinu dat predstavují (c) údaje o sledování podzemních vod. Jedná se o vydatnosti 114 pramenů a stavy hladin vody v 154 mělkých vrtech hlásné sítě ČHMÚ (2015b) převážně z let 1971-2013 většinou v týdenním, v př́padě vrtů v posledních letech i v denním kroku. Hluboké vrty nebyly zpracovány vzhledem $\mathrm{k}$ jejich krátkému pozorování a víceleté cyklicitě. Všechny řady splňují požadavek minimální délky s počátkem pozorování nejpozději od roku 1981, naprostá většina objektů pokrývá celé období od roku 1971. Za účelem jednotného hodnocení trendu byla i v těchto datech prítomnost trendu zjištována pro jednotlivé měsíce roku a pro roky a stejně jako u předešlé datové sady opět v oblasti průměrných a minimálních hodnot. Pro umožnění porovnání byla velikost trendu těchto veličin vyjádřena jako změna standardní odchylky (s).

\section{METODA}

Existence a velikost trendu byla šetřena pomocí neparametrického Mann-Kendallova testu a Senova odhadu směrnice trendu v prostredí R (R Core Team, 2014). Mann-Kendallův test je často používán pro analýzu trendu v datových sadách environmentálních systémů (Kendall, 1975; Libiseller a Grimvall, 2002). Jedná se o test neparametrický, který nepředpokládá normalitu dat a není citlivý vưči odlehlým hodnotám a nelineárním trendům nízkého stupně. Test lze použít v prípadech, kdy je v datových sadách předpokládána spojitá monotónní rostoucí nebo klesající funkce času a rezidua rozložení s nulovou střední hodnotou. Jinými slovy za předpokladu, že rozptyl rozložení je v čase konstantní.

Nulová hypotéza testu $H_{0}$ je, že pozorovaná data $\left\{X_{i}, i=1,2, \ldots n\right\}$ jsou nezávislá a se shodným rozdělením. Alternativní hypotéza $H_{1}$ je, že ve výběru dat je prítomen monotónní trend. Statistika S Mann-Kendallova testu je definována jako:

$$
S=\sum_{i=1}^{n-1} \sum_{j=i+1}^{n} \operatorname{sgn}\left(X_{j}-X_{j}\right)
$$

kde $\operatorname{sgn}(\Theta)=\left\{\begin{array}{lll}1 & \text { když } & \Theta>0 \\ 0 & \text { když } & \Theta=0 \\ -1 & k d y z ̌ & \Theta<0\end{array}\right.$

Mann (1945) a Kendall (1975) ukázali, že pro $n \geq 8$ je statistika S přibližně normálně rozdělená se střední hodnotou:

$$
E(S)=0
$$

a rozptylem:

$$
V(S)=\frac{n(n-1)(2 n+5)-\sum_{m=1}^{n} t_{m} m(m-1)(2 m+5)}{18}
$$

kde $t_{m}$ je počet skupin (dvojic, trojic atd.) shodných hodnot $v$ rozsahu $m$, přičemž $m=2$ pro dvojice shodných hodnot, $m=3$ pro trojice atd. Standardizovaná testová statistika $Z$ je potom:

$$
Z=\left\{\begin{array}{lll}
\frac{S-1}{\sqrt{V(S)}} & \text { když } & S>0 \\
0 & \text { když } & S=0 \\
\frac{S+1}{\sqrt{V(S)}} & \text { když } & S<0
\end{array}\right.
$$

Testová statistika Z má standardní normální rozdělení s nulovou střední hodnotou a rozptylem rovným jedné.

Von Storch (1995) ukázal, že přítomnost autokorelace $v$ časové řadě zvyšuje pravděpodobnost, že Mann-Kendallův test detekuje statisticky významný trend, tzn. že autokorelace zvyšuje pravděpodobnost chyby 1. rádu.

Pro zpracování časových řad byla proto použita varianta testu s korekcí autokorelace 1. rádu (Yue a Pilon, 2002). V této metodě je nejprve spočtena směrnice trendu podle Sena (1968). Je-li směrnice nenulová a statisticky významná, je z časové řady odstraněn trend daný touto směrnicí a v takto upravené řadě posouzena prítomnost autokorelace 1. rádu. Výsledná rezidua by měla být nezávislá. Je-li autokorelační koeficient statisticky významný, je směrnice trendu původní řady uplatněna na rezidua autokorelace a na této raadě je posouzena významnost trendu pomocí Mann-Kendallova testu. Výsledná směrnice trendu $b$ je opět počítána podle Sena (1968), tedy jako medián směrnic všech párů dat podle rovnice:

$$
b=\operatorname{med}\left(\frac{X_{j}-X_{i}}{j-i}\right), \forall i<j
$$

Statistická významnost trendu byla testována na hladině významnosti $a=0,05$. Do hodnocení byly zahrnuty pouze statisticky významné trendy. Výsledný trend sledovaných veličin je uváděn jako průměrná změna za desetileté období.

\section{VÝSLEDKY}

\section{Bilanční veličiny - průměry}

Mapy bilančních veličin jsou pro přehlednost uváděny převážně pouze pro deset bilančních oblastí (BO) a vývoj 74 bilančních povodí, který se v podstatě shoduje s bilančními oblastmi, je až na výjimku v případě odtoku zmíněn pouze $\checkmark$ textu, je-li to vhodné pro porozumění souvislostem. Při posuzování map je třeba prihlédnout ke skutečnosti, že četnost extrémních hodnot je dána volbou intervalů barevné škály. Objektivní měřítko toho, co představuje velký pokles nebo velký vzestup, neexistuje.

$\checkmark$ rámci změn sezonality srážek (obr. 1) byl v dubnu zjištěn trend jejich poklesu ve třech BO v severních a východních Čechách o průměrně 15-19\%, a naopak jejich nárůst v BO horní Vltava o 13 \% v červnu. V ročních řadách srážek byl zjištěn nárůst ročních úhrnů v BO horní Vltava o 5 \%.

U zásob vody ve sněhové pokrývce byl zjištěn pokles v BO Odra a Olše v prosinci o $17 \%$, v ročních agregacích změna zjištěna nebyla. V rámci ročního chodu teplot (obr. 2) byl zjištěn pouze nárůst, a to v celé ČR, v dubnu, červnu a v listopadu o $0,4-0,9^{\circ} \mathrm{C}$ a na Moravě i v červenci a srpnu o 0,5-0,7 ${ }^{\circ} \mathrm{C}$. Zvýšení teploty $\checkmark$ jednotlivých měsících je patrné i v ročních agregacích, kde se projevilo v BO dolní Labe, Berounka a Dyje zvýšením o 0,4 ${ }^{\circ} \mathrm{C}$. 

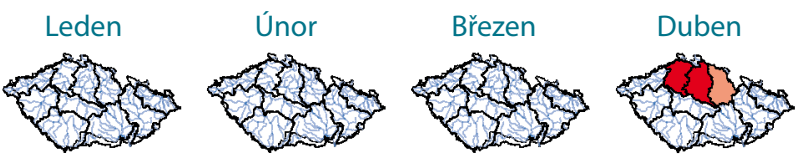

Květen
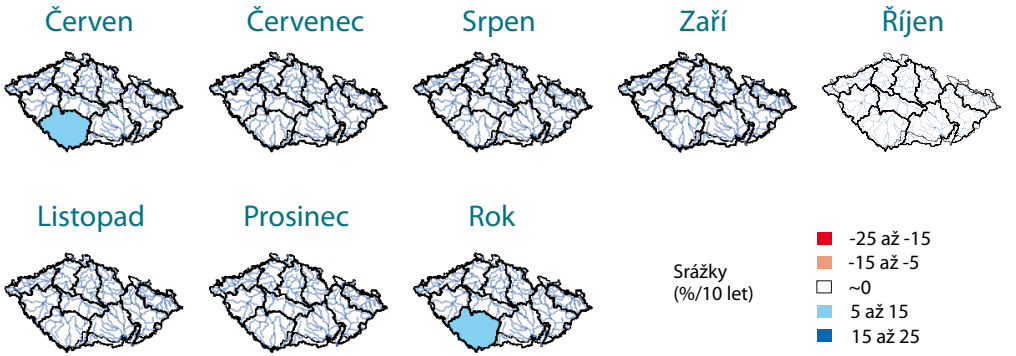

Rok

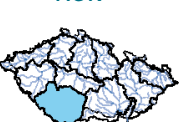

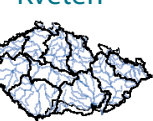

Říjen
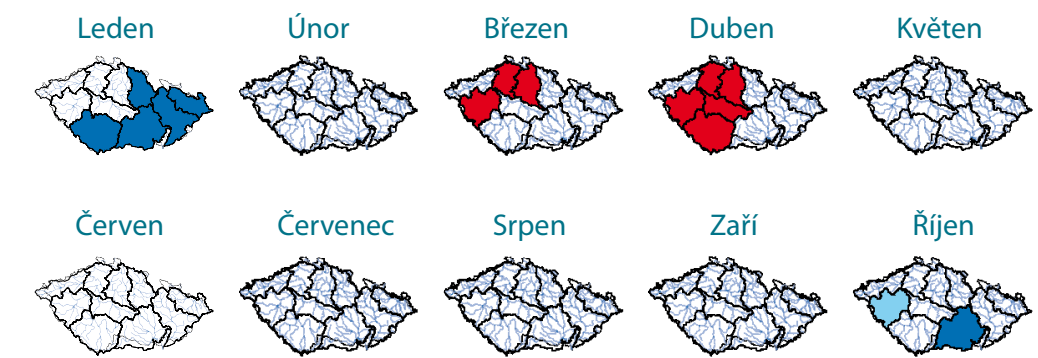

Říjen
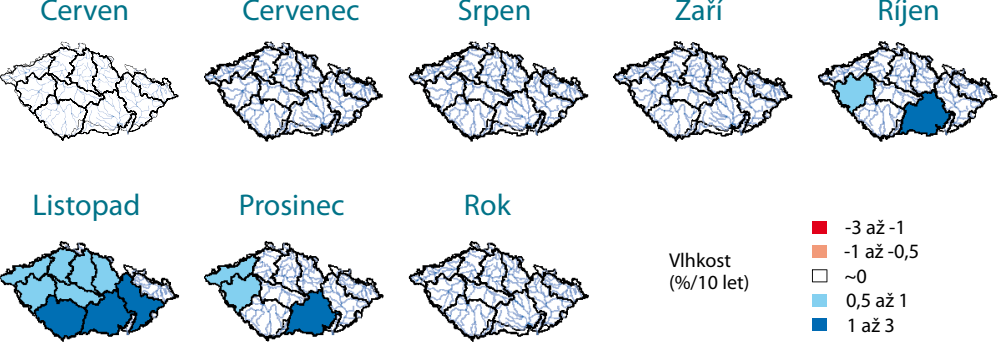

Rok

ních oblastech v období 1980-2013

Fig. 1. Linear trends (\%/10 years) in series of monthly and annual precipitation from

10 balance regions during the $1980-2013$ period
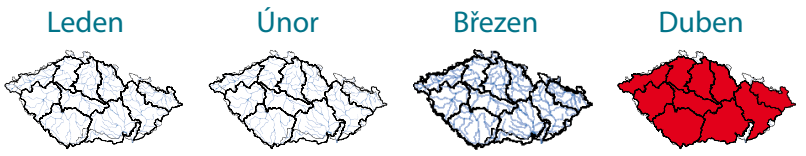

Květen

Červen

Červenec

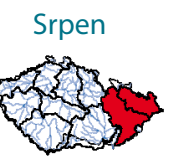

Zaří
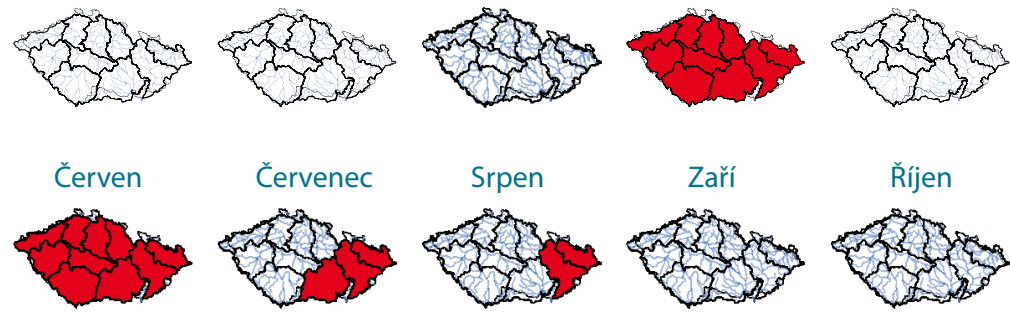

Rok
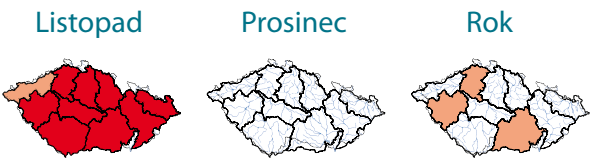

Teplota
$\left({ }^{\circ} \mathrm{C} / 10\right.$ let $)$

$\square-0$

- $-0,5$ až 0,2

$\square \sim 0$

0,2 až 0,5
0,5 až 1

Obr. 2. Lineární trendy $\left({ }^{\circ} \mathrm{C} / 10\right.$ let) řad průměrných měsíčních a ročních teplot vzduchu v deseti bilančních oblastech v období 1980-2013

Fig. 2. Linear trends ( ${ }^{\circ} \mathrm{C} / 10$ years) in series of mean monthly and annual air temperature from 10 balance regions during the 1980-2013 period

Relativní vlhkost vzduchu (obr. 3) roste $v$ lednu především na Moravě o 1-1,4\%, v listopadu v celé ČR o 0,5-1,5\% a také v říjnu a prosinci v BO Berounka a Dyje o 0,7-1,3\%, a naopak klesá v březnu a dubnu $\vee$ části BO $\vee$ Čechách o 1,2-1,8\%. V ročních průměrech se relativní vlhkost nezměnila.

Plošné rozmístění oblastí se zvyšující se potenciální evapotranspirací odráží zvýšení teplot tamtéž. V souladu se změnou ročního chodu teplot roste potenciální evapotranspirace $v$ celé ČR predevším v dubnu a v červnu o 3-7 \% a v listopadu až o 6-11\%, ovšem absolutní hodnoty potenciální evapotranspirace na konci roku jsou minimální a stejně tak i dopad tohoto zvýšení na vodní bilanci. Ke zvýšení o 2-3 \% dochází také na Moravě v červenci a srpnu. Kromě BO horní Labe, horní VItava, Ohře a Bílina bylo v ročních průměrech zjištěno zvýšení potenciální evapotranspirace $v$ sedmi ostatních BO ० 2-3 \%, které $\checkmark$ dlouhodobé perspektivě vytváří zvýšený tlak na vodní zdroje, podobně jako zvětšení potenciální evapotranspirace v dubnu a červnu.

Ke zvýšení aktuální evapotranspirace (obr. 4) dochází v měsících s dostupnou zásobou půdní vody pro výpar v reakci na případné zvýšení teploty, je tedy i výslednicí mírného zvýšení srážek na jihu a západě Čech, které lze dovodit z analýzy jednotlivých bilančních povodí. K nárůstu evapotranspirace tak
Obr. 3. Lineární trendy (\%/10 let) řad průměrných měsičních a ročních hodnot relativní vlhkosti vzduchu v deseti bilančních oblastech v období 1980-2013

Fig. 3. Linear trends (\%/10 years) in series of mean monthly and annual relative air humidity from 10 balance regions during the 1980-2013 period

$\checkmark$ rámci celého roku bylo zjištěno zvětšení evapotranspirace ve čtyřech $B O$ na jihu a západě ČR o 3-4 \%. Při posuzování těchto změn je přitom důležité, že velikost roční evapotranspirace je určována především charakterem kombinace teplot a srážek v období od dubna do října, či spíše od května do zárí.
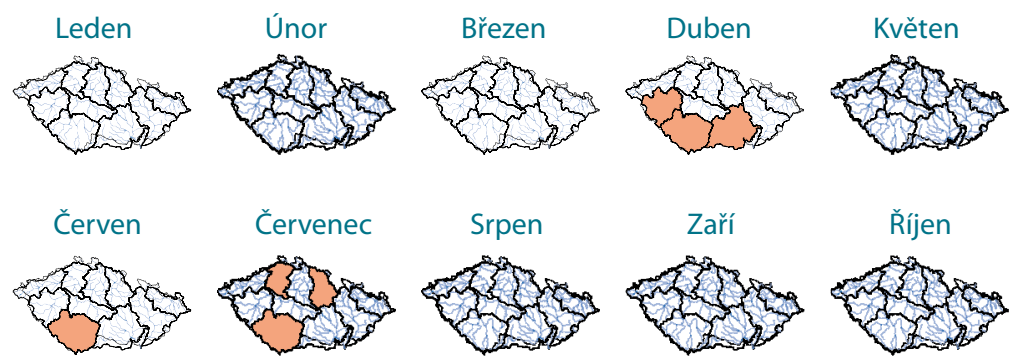

Říjen
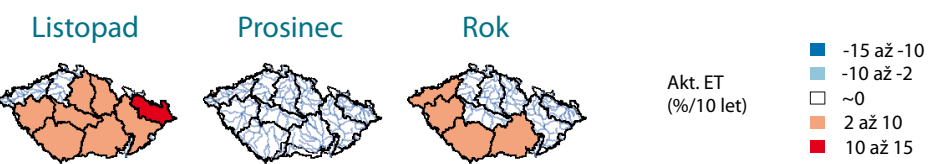

Obr. 4. Lineární trendy (\%/10 let) řad měsíčních a ročních hodnot aktuální evapotranspirace $\vee$ deseti bilančních oblastech $\vee$ období 1980-2013

Fig. 4. Linear trends (\%/10 years) in series of monthly and annual actual evapotranspiration from 10 balance regions during the 1980-2013 period 

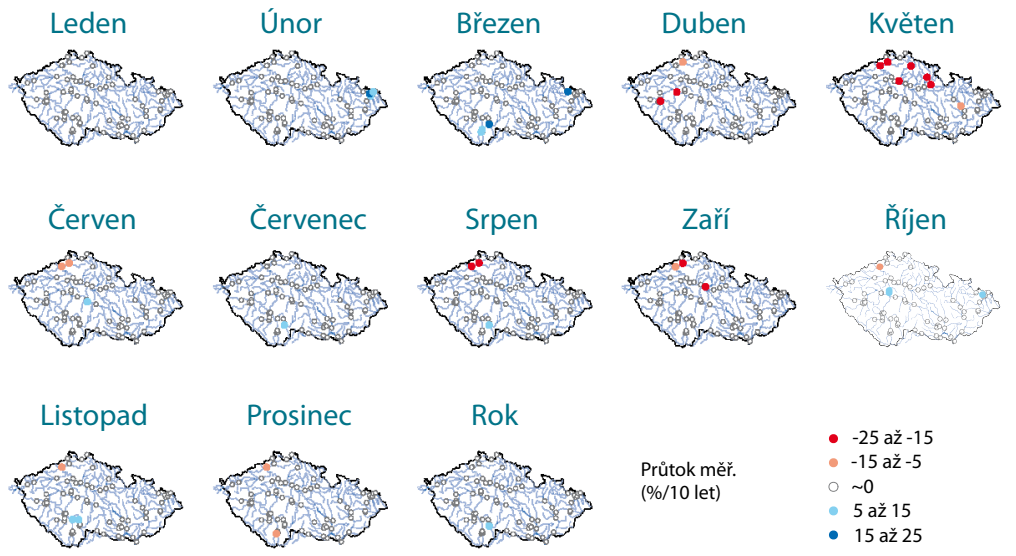

$$
\begin{aligned}
& -25 \text { až }-15 \\
& -15 \text { až }-5 \\
& \text { O } 0 \\
& \text { - } 5 \text { až } 15 \\
& \text { - } 15 \text { až } 25
\end{aligned}
$$

Obr. 5. Lineární trendy (\%/10 let) řad průměrných měsíčních a ročních měřených průtoků v 74 vodoměrných stanicích uzavírajících bilanční povodí v období 1980-2013 Fig. 5. Linear trends (\%/10 years) in series of mean monthly and annual measured discharge from 74 gauging stations monitoring balance river basins during the 1980-2013 period

Změny ročního chodu přirozeného odtoku do značné míry korespondují se změnami měřeného odtoku. $\vee$ některých $B O$ (Ohře a Bílina) se však výsledky zdají být ovlivněny způsobem očištění průtoků od vlivů především převodů vody, u obou typů odtoku pak i jeho vyčílením z mezipovodí, které je vždy zatíženo významnou chybou, tedy predevším v případě BO dolní Vltava a Sázava a BO dolní Labe. Ačkoli tedy byl v BO dolní Labe ve třech měsících detekován nárůst měřeného odtoku o průměrně $15 \%$ a podobně jeho pokles v BO Ohře a Bílina, nelze tyto výsledky vzhledem k povaze ovlivnění dat považovat za průkazné, a to i s ohledem na změny ročního chodu ostatních bilančních veličin, z jejichž vztahů takto výrazné změny odtoku nevyplývají. Změny odtoku jsou proto namísto mapy BO demonstrovány na bodové mapě vodoměrných stanic, které reprezentují ucelená bilanční povodí a kterých je podstatně více, takže prípadné změny odtoku regionálního rozsahu by byly zretetelnější.

Trend měřeného (obr. 5) i přirozeného odtoku je velmi podobný. Kromě poklesu odtoku v devíti bilančních povodích převážně na severovýchodě Čech o průměrně $17 \%$ v květnu byly $v$ ostatních měsících nalezeny trendy pouze $\checkmark$ ojedinělých prípadech, z kterých nelze vyvozovat obecné závěry. V řadách průměrných ročních měřených a přirozených průtoků nebyl zjištěn trend.
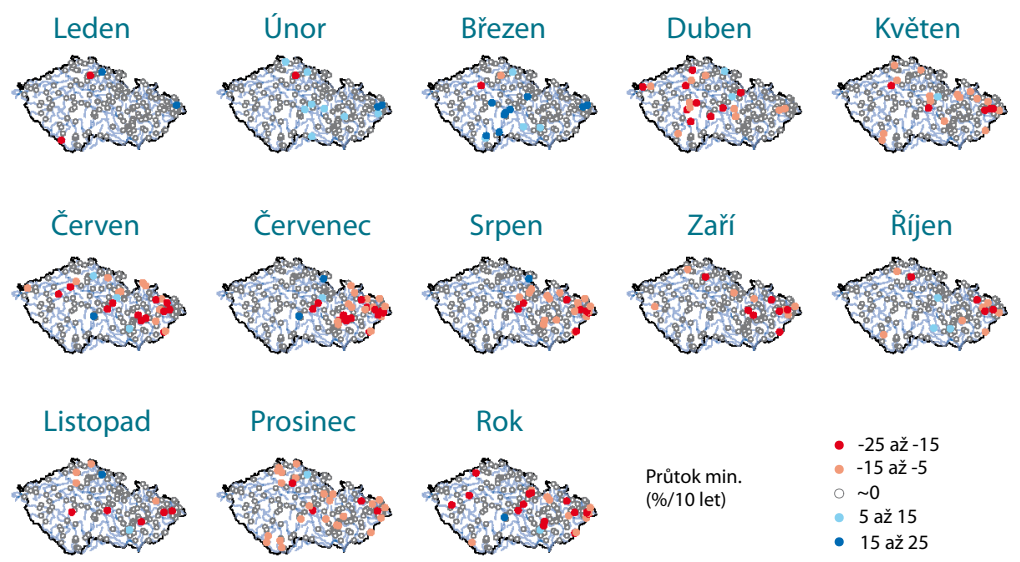

Obr. 6. Lineární trendy (\%/10 let) v řadách měsíčních a ročních sedmidenních klouzavých minim měřených denních průtoků pro 161 vodoměrných stanic v období 1971-2013 Fig. 6. Linear trends (\%/10 years) in monthly and annual series of 7-day running minimum discharges for 161 gauging stations in the 1971-2013 period

\section{Denní průtoky - průměry a minima}

Nejvýraznějšícharakteristikou trendu měsíčních průměrů denních průtoků ve 161 vodoměrných stanicích, kteréjsou využívány pro stanovenízákladního odtoku, je nárůst od toku v březnu u 31 stanic v pásu zjižních do východních Čech v prưměru o 15 \% a pokles v květnu u 32 stanic především v severních Čechách a na Moravě o průměrně $13 \%, v$ srpnu u 17 stanic převážně na severní Moravě o průměrně 10 \% a v prosinci, opět převážně na Moravě, výrazněji na severní, v průměru o 12 \% u 39 stanic. Změna v rámci jednotlivých měsíců není natolik výrazná, aby byla detekována v řadě průměrných ročních hodnot.

Pokles měsičních minim odtoku (obr. 6) je výraznějšín nežu měsíčních průměrů. Od dubna do prosince převažuje nebo byl zjištěn pouze pokles u 9 až 30 stanic (největší počty stanic v létě) od 12 do $17 \%$, přičemž poklesy jsou četnější a výraznější na Moravě a v severovýchodních Čechách. Podobně jako u průměrných hodnot i v minimech byl v pásu z jižních do východních Čech zjištěn nárůst odtoku v březnu průměrně o $19 \%$, ale stanic je méně, pouze 13. Poklesy v měsićcních minimech jsou natolik výrazné a v průběhu roku časté, že se projevují i poklesy ročních minim, kde u 25 stanic byl zjištěn pokles průměrně o $18 \%$. Nárůsty minim jsou výjimečné, týkají se pouze dvou stanic.

\section{Základní odtok - průměry a minima}

Změny prưměrného měsíčního základního odtoku z hlediska plošného rozšíření sledují změny celkového odtoku. Poklesy se tedy projevují nejvíce na Moravě (výrazněji na severní), v severovýchodních Čechách, na jaře více v Čechách. Nárůsty jsou výjimečné, zatímco výrazně převažuje pokles kromě března ve všech měsících roku, nejvýrazněji v lednu, v období od května do srpna a $\vee$ prosinci u 16 až 30 stanic průměrně o 14 až $16 \%$. Došlo také ke změně ročních průměrů základního odtoku, kdy u 15 stanic byl zaznamenán pokles průměrně o $14 \%$ a u šesti stanic nárůst průměrně o $8 \%$.
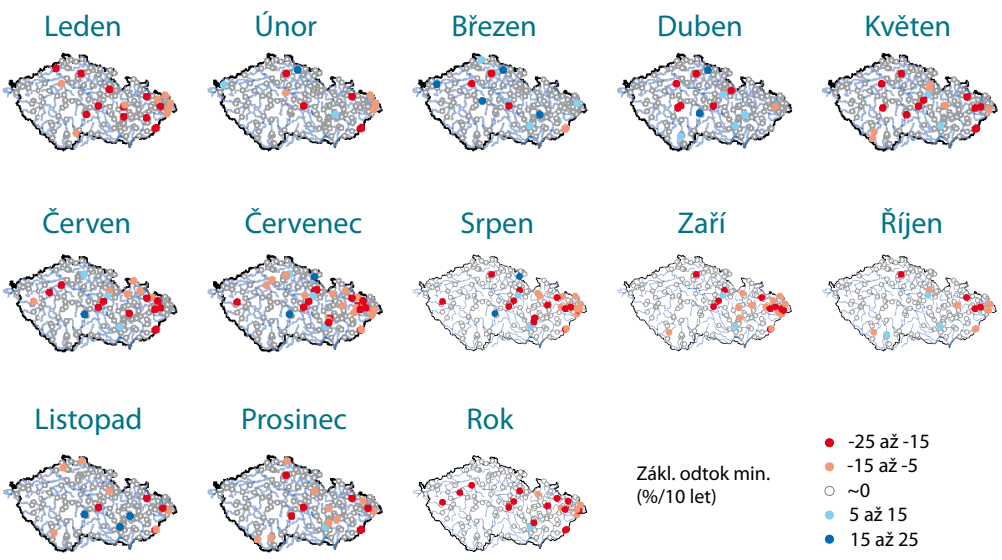

Obr. 7. Lineární trendy (\%/10 let) v řadách měsíčních a ročních sedmidenních klouzavých minim separovaného základního odtoku pro 161 vodoměrných stanic na území České republiky v období 1971-2013

Fig. 7. Linear trends (\%/10 years) in monthly and annual series of 7-day running minimum baseflow for 161 gauging stations situated in the Czech Republic in the 1971-2013 period

Plošné rozšiřrení velikosti a koncentrace změn měsíčních minim základního odtoku je stejné jako u průměrných hodnot, výrazně ale převažuje pokles, kromě března ve všech měsících roku, opět nejvýrazněji v lednu, od května do srpna a v prosinci, a to u 16 až 30 stanic průměrně o 14 až $18 \%$. Podobně i u ročních minim byl u 22 stanic zjištěn pokles průměrně o 19 \% a pouze u dvou stanic nárůst průměrně o 7 \% (obr. 7). 


\section{Vrty - průměry a minima}

U průměrných měsíčních stavů hladin v mělkých vrtech překvapivě převažuje v zimním půlroce (listopad až duben) vzestup hladin (23 až 42 vrtů) nad poklesy (5 až 18 vrtů), v letním půlroce byly zaznamenány přibližně stejně četné vzestupy i poklesy, a to u 12 až 20 vrtů. Poklesy v letní části roku se vyskytují spíše v severovýchodních Čechách a na severní Moravě. Průměrná velikost vzestupu v zimním půlroce činí 0,28-0,32 násobek směrodatné odchylky s. Z hlediska průměrných ročních stavů hladin ve vrtech byl zjištěn u 24 objektů vzestup průměrně o 0,28 s a u 12 objektů pokles o 0,29 s.

U minimálních měsíčních stavů hladin (obr.8) také převažuje v zimním půlroce vzestup u 22 až 34 vrtů průměrně o 0,26-0,29 s nad poklesy, kterých je pouze 9 až 13 o velikosti průměrně $0,25-0,32$ s. $V$ letním půlroce početně mírně převažují poklesy nad vzestupy, objektů se zvyšující se hladinou je 18 až 28 oproti 14 až 19 vrtům, u kterých došlo ke snížení hladiny. Velikost zvýšení je v rozsahu průměrně 0,26-0,31 s a velikost snížení hladiny činí prakticky stejně 0,27-0,35 s. Vrty s poklesem hladiny jsou soustředěny opět v severovýchodních Čechách a na severní Moravě, vrty s vzestupem hladiny poněkud prekvapivě na jižní Moravě. U ročních minim stavů hladin prevažují vzestupy (24 vrtů; 0,3 s) nad poklesy (15 vrtů; 0,27 s), vzestupy jsou koncentrovány na jihu Moravy.
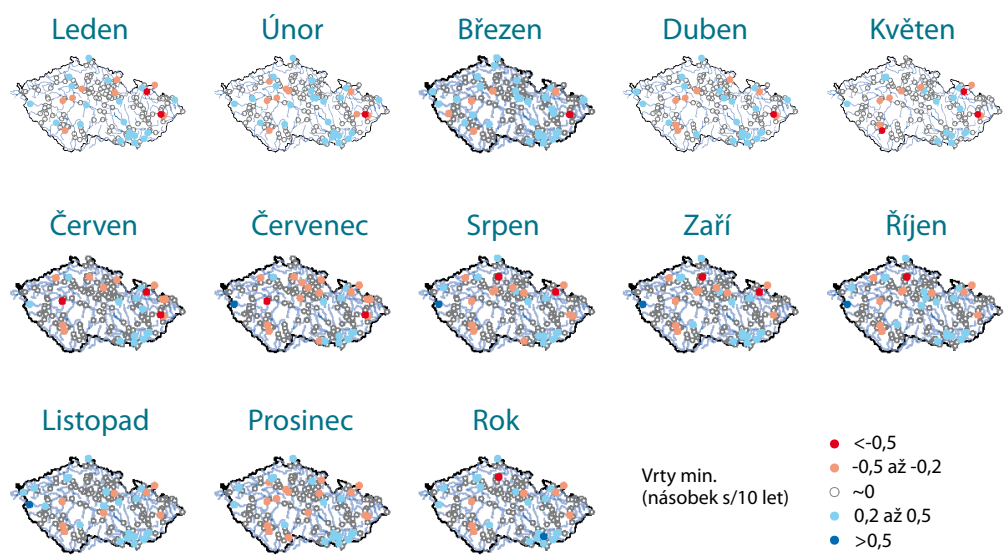

Obr. 8. Lineární trendy (násobek směrodatné odchylky s/10 let) minimálních měsíčních a ročních stavů hladiny 154 mělkých vrtů v období 1971-2013

Fig. 8. Linear trends (multiples of standard deviation s/10 years) recorded as monthly and annual minima for 154 shallow borehole levels in the 1971-2013 period

\section{Prameny - průměry a minima}

Plošné rozšíření i velikost a orientace trendu průměrných i minimálních (obr. 9) měsičních vydatností pramenů jsou prakticky totožné. S výjimkou března u průměrných vydatností zřetelně po celý rok převažují poklesy nad nárůsty, klesla vydatnost približně 16 až 26 pramenů, nárůsty byly zjištěny u jednoho až devíti pramenů. Poklesy jsou větší, o velikosti v případě průměrů nejčastěji 0,35-0,54 s, minim 0,31-0,49 s, s nárůsty velmi podobnými, které u průměrů představují 0,32-0,53 s, u minim 0,32-0,57 s. U ročních prưměrných i minimálních vydatností převažují poklesy nad nárůsty, přičemž pokles o velikosti 0,41 s, resp. 0,37 s byl zjištěn u 18, resp. 20 objektů, zatímco vzestup o velikosti 0,39 s, resp. 0,24 s u tří, resp. šesti objektů. Objekty s poklesem vydatnosti jsou výrazně soustředěny na severu Čech, což by bylo možné přičítat spíše zpưsobu měření a jejich vyhodnocení než prirrozeným prríčinám. Pokles vydatností se také často vyskytuje u pramenů střední Moravy.
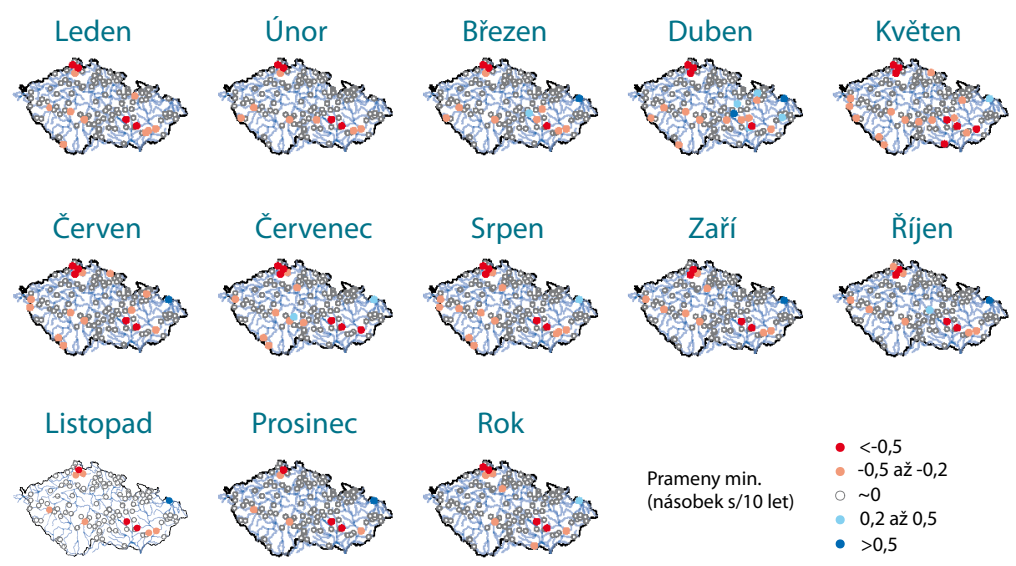

Obr. 9. Lineární trendy (násobek směrodatné odchylky s/10 let) minimálních měsíčních a ročních vydatností 114 pramenů v období 1971-2013

Fig. 9. Linear trends (multiples of standard deviation s/10 years) recorded as monthly and annual minima for 114 springs in the 1971-2013 period

\section{ZÁVĚR}

V řadách hodnocených bilančních veličin byl mezi lety 1980-2013 zjištěn především vzestup průměrných ročních teplot v části ČR o $0,4^{\circ} \mathrm{C}$ za desetiletí a vzestup teplot $v$ celé ČR $v$ dubnu, červnu a v listopadu o $0,4-0,9^{\circ} \mathrm{C}$ a na Moravě i v červenci a srpnu o $0,5-0,7^{\circ} \mathrm{C}$. Srážky poklesly v severních a východních Čechách v dubnu průměrně o 15-19 \%, a naopak vzrostly na jihu Čech o 13 \% v červnu, což se celkově projevilo nárůstem ročních úhrnů srážek na jihu Čech o $5 \%$. Zásoba vody ve sněhové pokrývce poklesla v prosinci na severu Moravy o $17 \%$. U relativní vlhkosti vzduchu došlo ke změně ročního chodu v rádu 0,5$1,5 \%$. Vlhkost vzrostla v chladnější části roku predevším na Moravě, popř. v celé ČR, a naopak klesla na jaře $v$ části Čech. K nárůstu evapotranspirace dochází v dubnu, červnu a červenci v jihozápadních Čechách o 2-3 \% a o 3-4 \% zde vzrostla evapotranspirace i v rámci celého roku.

Z bilančního hlediska tedy došlo k poklesu srážek v severních a východních Čechách v dubnu, jejich nárůstu na jihu Čech v červnu i v rámci roční bilance, k poklesu zásob sněhu na severní Moravě, k vzestupu teplot v teplé části roku v Čechách a ještě výrazněji na Moravě a dále k nárůstu evapotranspirace v jihozápadních Čechách vlivem kombinace vyšších teplot a dostupnosti vody v důsledku vyšších srážek. Kromě vyšších srážek na jihu Čech se jedná výhradně o faktory, které dostupnost vodních zdrojů ovlivňují negativně. Těmto trendům a jejich lokalizaci odpovídá i pokles odtoku v části bilančních stanic na severovýchodě Čech průměrně o $17 \%$ v květnu.

Těmto zjištěním odpovídá i pokles odtoku v sadě 161 vodoměrných stanic mezi lety 1971-2013 v květnu především v severních Čechách a na Moravě o průměrně $13 \%$ za desetiletí, v srpnu a prosinci na severní Moravě. U části stanic ale také odtok vzrostl, nicméně je kompenzován $v$ jiných částech roku. $\checkmark$ minimech odtoku poklesy převažují nad vzestupy, nejvíce poklesů je v létě a $v$ prủběhu celého roku jsou četnější a výraznější na Moravě a v severovýchodních Čechách, pokles je zřetelný i v roční bilanci. Změny průměrného základního odtoku jsou podobné jako změny celkového odtoku. Poklesy se tedy projevují nejvíce na Moravě, výrazněji na severní, a v severovýchodních Čechách. Minima základního odtoku se mění výrazněji, převažuje pokles nad vzestupy, kromě března ve všech měsících roku, nejvýrazněji v lednu, od května do srpna a $v$ prosinci.

Ačkoli tyto závěry mohou při častém užívání výrazu „pokles“ vyznívat pesimisticky, platí, že na výrazné většině stanic nebyl zjištěn statisticky významný 
trend. Na druhé straně je ovšem zřejmá shoda v rozšířeném výskytu z hlediska vodních zdrojů negativního trendu na severovýchodě ČR.

$\checkmark$ průběhu roku i v roční bilanci byl dále u průměrných i minimálních vydatností rady pramenů mezi lety 1971-2013 zjištěn pokles kolem 0,4 s za desetiletí, zvětšení vydatností je nevýrazné, ale u většiny objektů nebyla zjištěna žádná změna.

Do celkového obrazu príliš nezapadá vývoj hladin mělkých vrtů. U minim $\checkmark$ letním půlroce sice početně mírně převažují poklesy nad vzestupy, oboje o velikosti kolem 0,3 s, ale v zimním půlroce je naopak častější vzestup. V roční bilanci mírně převažují vzestupy hladin, ale u velké většiny objektů nedochází k žádné změně. U průměrných hladin bylo vzestupů hladin zjištěno více.

\section{Poděkování}

Článek vznikl na základě dat a výsledků Českého hydrometeorologického ústavu.

\section{Literatura}

ČHMÚ. (2015a) Bilance množství a jakosti vody ČR [online], ČHMÚ [cit. 2015-03-20]. Dostupné z: $<$ http://voda.chmi.cz/opzv/bilance/bilance.htm>

ČHMÚ. (2015b) Stav podzemních vod [online], ČHMÚ [cit. 2015-03-20]. Dostupné z: <http:// portal.chmi.cz/portal/dt?menu=JSPTabContainer/P10_0_Aktualni_situace/P10_2_Hydrologie/ P10_2_3_Stav_podzemnich_vod\&last=false $>$.

Eckhardt, K. (2005) How to construct recursive digital filters for baseflow separation. Hydrological Processes, 19, p. 507-515.

Fiala, T., Ouarda, T.B.M.J., and Hladný, J. (2010) Evolution of low flows in the Czech Republic. Journal of Hydrology, 393, p. 206-218.

Hanel, M. aj. (2011) Odhad dopadů klimatické změny na hydrologickou bilanci v ČRa možná adaptační opatření. Praha: VÚV TGM, 108 s., ISBN 978-80-87402-22-1.

Kendall, M.G. (1975) Rank correlation methods. London: Griffin.

Ledvinka, O and Lamačová A. (2015) Detection of field significant long-term monotonic trends in spring yields. Stochastic Environmental Research and RiskAssessment, 29, p. 1463-1484. doi:10.1007/s00477-014-0969-1.

Mann, H.B. (1945) Nonparametric tests against trend. Econometrica, 13, p. 45-259.

Libiseller, C and Grimvall, A. (2002) Performance of partial Mann Kendall tests for trend detection in the presence of covariates. Environmetrics, 13, p. 71-84.

R Core Team. (2014) R: A Language and Environment for Statistical Computing. R Foundation for Statistical Computing, Vienna, Austria. URL http://www.R-project.org.

Sen, P.K. (1968) Estimates of the regression coefficient based on Kendall's tau. Journal of the American Statistical Association, 63, p. 1379-1389.

Von Storch, V.H. (1995) Misuses of statistical analysis in climate research. In Analysis of Climate Variability: Applications of Statistical Techniques, von Storch, H. and Navarra, A. (eds). Berlin: Springer-Verlag, p. 11-26.

Yue, S., Pilon, P., Phinney, B., and Cavadias, G. (2002) The influence of autocorrelation on the ability to detect trend in hydrological series. Hydrological Processes, 16, p. 1807-1829.

\section{Autor}

Ing. Radek VInas ${ }^{1,2}$

凶radek_vlnas@vuv.cz

${ }^{1}$ Výzkumný ústav vodohospodářský T. G. Masaryka, v.v.i.

2 Český hydrometeorologický ústav

Príspěvek prošel lektorským řízením.

\section{OBSERVED CHANGES OF HYDROLOGICAL BALANCE COMPONENTS REGARDING THE AVAILABLE WATER RESOURCES}

\section{VLNAS, Radek ${ }^{1,2}$}

${ }^{1}$ T. G. Masaryk Water Research Institute, p.r.i.

${ }^{2}$ Czech Hydrometeorological Institute

Keywords: hydrological balance - trend $-\mathrm{R}-$ stream flow - water sources - baseflow - boreholes - springs

This study investigated changes in time series of hydrological balance components using trend detection. A various sets of data were available, such as data from the report "Hydrological balance of water quantity and quality in the Czech Republic", the report of natural sources of groundwater and groundwater regime assessment, in order the potential change of hydrological cycle to be comprehensively observed. Although the time series used are relatively short with length of some 30 or 40 years, the advantage is their similar period and thus possibility of comparison among the series. For trend detection the modified Mann-Kendall test removing lag-1 autocorrelation was used. The magnitude of the trend was described in mean monthly and annual series of precipitation, air temperature, evapotranspiration, stream flow and other variates, as well as in monthly and annual mean and minimum of daily stream flow and baseflow, spring yields and borehole levels. 